\title{
Luanda Through its Prisons: Luandino Vieira's Papéis da Prisão
}

\author{
MÓNICA V. SILVA \\ Universidade de Coimbra
}

\begin{abstract}
In this article, I analyze the Angolan author Luandino Vieira's prison writings, collected in the 2015 volume Papéis da Prisão-Apontamentos, Diário, Correspondência (1692-1971). As part of this analysis, I discuss the role of colonial prisons under the Portuguese Estado Novo in the affirmation of Angolan national identity.
\end{abstract}

Keywords: Angola; Prison narrative; Nationhood; Estado Novo

Political prisoners' experiences of incarceration have produced a range of written accounts that denounce injustice, effect resistance, and preserve memory. ${ }^{1}$ These writings take different forms: diaries, works of critical thought, letters, poems, short stories, and novels. Some move from the present to the past, as memories, others from the past toward the future, like a testimony in actu. In this article, I examine the role of Luanda prisons in the Angolan struggle for freedom against Portuguese colonialism and in the affirmation of the Angolan nation, particularly

\footnotetext{
${ }^{1}$ This text is based on a paper presented at international conference "Luanda and Maputo: The urban space in literature" held at the Centre of Social Studies, University of Coimbra (25 September, 2015). It was written in the context of my work developed as a doctoral student in "Heritages of Portuguese Influence" (Institute of Interdisciplinary Research and Centre of Social Studies, University of Coimbra) and junior researcher for the project "José Luandino Vieira - Tarrafal Diaries" funded by the Calouste Gulbenkian Foundation. It results from the project "De S. Paulo de Luanda a Luuanda, de Lourenço Marques a Maputo: capitais coloniais em tempos pós-coloniais" (PTDC/CLELLI/122229/2010 - FCOMP-01- 0124-FEDER- 019830), which was financed by Fundos FEDER through the Programa Operacional Factores de Competitividade and by the Fundação para a Ciência e a Tecnologia.
} 
during the lengthy liberation war from 1961 to 1974. Based on Luandino Vieira's prison writings, I offer an itinerary through this other side of the independence struggle.

In 2015, 43 years after his release from prison, Luandino published Papéis da Prisão, a set of seventeen notebooks composed of political, literary, and intimate texts, written in prison between 1961 and 1972. Throughout the notebooks, the writing location took precedence, constraining the actual process of composition, packaging, and preservation. Luandino appropriates the act of writing as an instrument to reveal the experience of the self, as well as an experience of the "collective." Papéis da Prisão is a book that both imprints an identifying narrative of an individual path at a specific historical moment and confirms the existence of a nation before its independence, thus justifying and consolidating the fight.

\section{The jails of Luanda as spaces of national struggle}

After the Second World War, Luanda became a center of anti-colonial activity linked to others on the African continent. The imperialist vision of Portuguese cultural hegemony, denounced by figures such as Aimé Césaire and Amílcar Cabral, began to be clandestinely but assertively confronted through the affirmation of cultural movements based on other systems of meaning. Luanda's cultural movements represented this new form of discourse and were hence instrumental in establishing notions of difference from colonial culture and promoting the unity of the Angolan nation. They decried heterogeneous experiences of violence, exploitation, and domination, and they summoned subjects to take a political stance against oppression and for freedom.

Luanda's cultural movements from the late nineteenth and the first half of the twentieth century laid much of the groundwork for the nationalist political organizations of the second half of the twentieth century. While other contextual factors played their part, including a changed international climate that no longer favored colonialism, those proto-nationalistic expressions, most associated with newspapers, initiated the mapping of Angola that, though it followed certain Portuguese canons, particularly in its literary production, began to establish differences. They reflected other realities, with other words and other dreams. By 1948, the "Vamos descobrir Angola" movement emerged in Luanda, composed 
of a group of young people who understood themselves to be descendants of the "combative spirit" and Afro-centric stance of the nineteenth- and early twentiethcentury writers who preceded them (Andrade 6). In 1945, the Sociedade Cultural de Angola had launched the Boletim Cultura that lasted until 1951. In 1951, the Cultural Department of the Associação dos Naturais de Angola (Anangola) launched the magazine Mensagem. In 1953, the Jornal de Angola was founded and lasted until 1965. It was also in the late 1950s that the Sociedade Cultural de Angola increasingly became a space for the discussion of literary, philosophical, cultural, and political issues. In 1957, it relaunched Cultura as a newspaper, which lasted until 1960. Writing was assumed to be a space to denounce colonial rule and to think and imagine the new nation. The writer was a potential agent in the struggle. These movements, influenced by the Harlem Renaissance and Négritude, as well as the literary current initiated by Césaire and Léopold Sédar Senghor, sought to move cultural production into the terrain of difference. By projecting certain senses of belonging, commitment, and a future onto a space whose territorial borders were the result of European imperial negotiations, they enabled Angola's emergence as an independent entity. Through writing, they created the framework for the union between territory and identity, contributing to the birth of "angolanidade."

The 1950s also saw the emergence of several clandestine political organizations. In 1954, the Union of the Populations of Northern Angola (UPNA) was founded, transforming in 1958 into the Union of the Populations of Angola (UPA). In 1955, the Communist Party of Angola came into being, and in 1956 the Movimento Popular de Libertação de Angola (MPLA) was officially born.

At the same time, repressive colonial policies were reinforced in Angola. In 1954, the metropolitan prison system of 1936 was moved to the overseas territories..$^{2}$ In the same year, the Polícia Internacional e de Defesa do Estado (PIDE) officially arrived in Angola, with its headquarters in Luanda. In 1959, the first political arrests of several Angolan intellectuals took place. A stream of politically motivated prosecutions that became known as the "Processo dos 50" produced, according to Maria do Carmo Medina, a structural shock reflected in

\footnotetext{
${ }^{2}$ Decree-Law 39:997 of 29 December, 1954. The Decree-Law 26: 643 of 28 May, 1936 had determined for mainland Portugal the different formats and functions of prison establishments and the new modalities of punishment (fines, prison, and banishment).
} 
the very essence of colonial society and caused a chain reaction of historical events. The events of 4 February, 1961, celebrated as the start of the armed struggle for the independence of Angola, were prompted by an effort to liberate political prisoners incarcerated in the Casa de Reclusão Militar, São Paulo Prison, and Catete Road Police Station (Medina 79).

In the aftermath of these events, on 20 November of the same year, the writers António Jacinto, António Cardoso, and José Vieira Mateus da Graçamore commonly known as Luandino Vieira, the name he would officially adopt in 1976-were imprisoned because of their opposition to colonial rule. They received the longest sentences ever handed down to any political prisoners in Angola (Medina 97).

The political incarceration of the three writers was meant to isolate them as individuals regarded as threats to the security of the State. As Edward Said notes, in the context of the European colonies, writers embody in themselves and in their writing a symbolic role that confers a public identity on them (156). Their imprisonment, therefore, can also be understood as the attempted annihilation of a cultural identity that clashed with Portuguese territorial and ideological designs.

In the history of the Angolan liberation movement, the importance of Luanda's prisons cannot be overstated. In 1959, the prisons sought to stifle the cultural expression of difference. By February 4 1961, the same spaces worked as a trigger for the assertion of difference and marked the germination of the armed struggle. They were spaces that confined opponents of colonialism. As a concept and a space, which contributed decisively to the restoration of a collective national consciousness, the prison is a key element in understanding the city of Luanda and the dynamics of the liberation movements, as Luandino's prison writings exemplify.

Papéis da Prisão bears witness to the experience of confinement, loneliness, and torture. However, the writer's forced removal from Luanda's social fabric ended up, ironically and contrary to the purposes of his harsh sentence, subverting Portuguese colonial power and strengthening an Angolan national consciousness. Colonial prisons were spaces of contact and sociability among prisoners from all over Angola, spaces where the nation-to-be could be felt and envisaged. Luandino's sense of nationhood and faith in the anti-colonial struggle was strengthened there. Those years of imprisonment gave him the opportunity to observe his companions, to listen to their stories, to became familiar with their 
beliefs, customs, and languages and from there to develop a literature that was intrinsically a project of national liberation.

\section{Luanda written by a political prisoner: Papéis da Prisão}

Luandino was imprisoned in the early days of the struggle for independence, first in 1959 and again in 1961. On this second occasion, he was condemned for crimes against national security, pursuant to article 141, number 1, of the Penal Code of 1961, for "intentar, por meio violento ou fraudulento, separar a MãePátria ou entregar a país estrangeiro todo ou parte do território português." $\mathrm{He}$ was sentenced to fourteen years in prison. From 1961 to 1964 , he was held in various jails in Luanda: the Pavilhão Prisional da Polícia Internacional e de Defesa do Estado (PPPIDE), the Cadeia do Comando da Polícia de Segurança Pública (PSP) and the Cadeia Comarcã. ${ }^{3}$ In 1964, he was sent to Chão Bom detention camp, Tarrafal, Cabo Verde, where he remained until 1972; he was then transferred to Lisbon under house arrest until 1974.

While Luandino's literary and political project was already in motion before 1961, it was in prison that it took shape. During his twelve years of effective detention, he produced a large part of his fictional writing and filled the seventeen notebooks that would become the Papéis da Prisão. ${ }^{4}$ The notebooks are composed of approximately 2,000 fragile handwritten pages, full of fragments: diary annotations, correspondence, postcards and drawings, popular traditional songs collected from other prisoners, literary sketches and translation exercises, Kimbundu oral and written folklore, newspaper cuttings, and notes. They are a fertile deposit of material in which Luandino records his anguish, his dreams, his political and literary ideals, and portrays the common project of Angola as a vehicle of union and collective resistance (Ribeiro and Vecchi 17). He also depicts his vision of the city of Luanda, one born of a multiplicity of perspectives.

\footnotetext{
${ }^{3}$ Also known as Luanda Civil Jail or Luanda Central Jail.

${ }^{4}$ Luandino wrote many short stories during his incarceration in Luanda's jails, published in the volumes Luuanda (1964); Vidas Novas (1968); and Velhas Estórias (1974). While in Tarrafal, he wrote stories later published as Nós, os do Makulusu (1974); João Vêncio: os seus amores (1979); No Antigamente, na Vida (1974); Macandumba (1978); and Lourentinho Dona Antónia de Sousa Neto e Eu (1981). The first edition of Luuanda won the Grande Prémio de Novelística da Sociedade Portuguesa de Escritores, in 1965.
} 
Luandino's descriptions of Luanda's prisons corroborate their important role in the anti-colonial struggle. Through the prison trajectories narrated in Papéis da Prisão (both the author's and those of his companions), it is possible to expand the geography of the prisons and see them as part of a system that functioned as a network, including colonial urban prisons, detention camps, and the metropolitan prisons where nationalists were detained. ${ }^{5}$ In this security system that used arbitrary arrests, detention without trial, transfer, isolation, torture, and other forms of aggression, doubt haunted the prisoners, accentuating the sense of vulnerability they felt. Note how Luandino questions the absence of a fellow prisoner: "Teria sido transferido para S. Pedro? Mandado para os campos de concentração da Damba ... ou Moçâmedes?" (93). ${ }^{6}$

Overcrowding as an issue in Luanda's prison becomes apparent when Luandino describes the situation in the PPPIDE in January 1963:

Na sexta-feira houve muita roupa, muitas comidas a entrar (pão grande, kitaba, quikuanga, farinha musseque etc. etc.) o que demonstrou estar a cadeia cheia. (Só na cela 2 estão 38 disse o Pescador, dormem 2 em cada cama). (Papéis da Prisão 80)

A cela 2 tem actualmente 11 camas individuais, o espaço no máximo é para 12 camas indiv., portanto, 12 indivíduos. Há actualmente 30 a viver (!) lá e o máximo que lá houve foram 40! (Papéis da Prisão 94)

The notebooks paint a portrait of Luanda's jails filled with inmates from every social class, from intellectuals to lumpenproletariats, and from a vast array of places, from Angola and Portugal to other countries. This heterogeneous mix of inmates put difference at the center of the anti-colonial struggle. Diversity did not just apply to political prisoners but to also common prisoners, many of whom

\footnotetext{
${ }^{5}$ During his first imprisonment (1959), Luandino was held in the Casa de Reclusão Militar. During his second (1961), he was held in Aljube (Portugal) for less than a week before being transferred to Luanda, from 1961 to 1964, and then to Tarrafal, from 1964 to 1972.

${ }^{6}$ Fortaleza de São Pedro da Barra (at the entrance of Luanda Bay), Colónia Agrícola para Indígenas da Damba (Malanje); Campo Prisional de São Nicolau (Moçâmedes, the colonial name for Namibe).
} 
lived, before their jail time, on the margins of society. They were often prisoners of circumstance, whose fate had been determined by hunger, social exclusion, geography, skin color, and a lack of access to education and employment.

In an interview given in 2015, Luandino asserts that he was arrested for "deliberação própria," just like every prisoner: "era uma decorrência da luta que estávamos a travar.... Uns morriam, outros iam presos" (Papéis da Prisão 1072). Prison was par for the course. Those fighting for independence knew it was a possibility. "Estávamos todos, uns aqui, outros ali, uns com muros, outros com muros mais altos, outros nos outros campos" (Papéis da Prisão 1053). The walls to which Luandino refers circumscribed a nation trapped within and beyond the prison. Colonialism and coloniality were a structural prison that affected everyone. The physical structure of the prison spaces and their use mirrored the existence of a larger "national" prison, with all its racial, class, and legal divisions. According to Luandino, the PPPIDE prison "estava dividida: de um lado estariam os assimilados, do outro, estariam os indígenas.... Por vezes estava tudo misturado e a PIDE não fazia assim grandes diferenças, porque a atuação deles era diferente" (Papéis da Prisão 1045). The colonial concept of "indígenas" refers to a racial, social and cultural differentiation that created more segregation in civil society and had been transferred to prisons, as the prison fragment from 23 January, 1963, about an everyday situation in the PPPIDE discloses:

Vi a porta de comunicação com a cadeia da administração aberta.... Pela $1 .^{\mathrm{a}}$ vez eu via aquele pátio.... Junto à porta 3 presos ... um rapaz negro claro ... [um] negro gordo de óculos e bigode e outro mulato.... Foi tão grande a surpresa que ficámos os 4 a olhar uns para os outros sem nada dizer ... fiquei sem fala a ver aqueles a quem a ordem colonial mesmo na prisão, ainda separa de nós. (107)

This fragment reveals the separation at the core of the colony: whites and the "assimilated" were at the Prison Pavilion of PIDE separated by gates from the Administration Prison or "Funji," the place for blacks and indigenous mestiços. ${ }^{7}$

\footnotetext{
${ }^{7}$ In colloquial language, the Cadeia da Administração at the PPPIDE was called the Funji. Funji, a cheap foodstuff associated with the lower classes, is tied up with racial
} 
Luandino describes daily life in jail as an allegory of Portuguese colonialism in Angola. Descending from feelings of superiority and deeply rooted racism, the quotidian in prison spaces unmasked the fallacy of legal "egalitarian" language. While the abolition of the Estatuto do Indígena (1961) sought to demonstrate a minimal change in racial practices in the public sphere, in prisons it meant absolutely nothing for the situation of the marginalized. The racial and ethnic distinction between prisoners, recounted with ironic humor, laid bare the inconsistencies of "integrationist" policies:

Este, em vez de pedir para o hotel + comida porque a que mandaram era insuficiente, deu esta ordem famosa, demonstradora da discriminação racial aqui mesmo na cadeia política:

- Para os brancos 2 pastéis, para os pretos 1 pastel!

O que o 121 veio repetir diante de cada cela. Ficou de boca aberta a gaguejar quando lhe perguntei:

- E os mulatos? Recebem como os brancos ou como os pretos?

(Papéis da Prisão 244)

This dichotomy reveals much more than the "skin color," which is, as Frantz Fanon argues in Black Skin, White Masks (1952), the language and positioning of a body within a system of meaning invented by European modernity. Being "black" or "white" was not merely the expressions of race. Racial and ethnic differentiation was inscribed both in the physical structure of the prison and its functioning, and on historically "classified" bodies. "Race" impregnated all social life in prison. In his writing, Luandino exposes the ideological contradictions and difficulties in thinking outside the frame of "naturalness" that defines and identifies categories, places, and roles attributed to individuals in the power relations of what Quijano defines as coloniality (74). This "naturalness" is exposed in the episode of the escape of two prisoners, white Ribas and black Mangololo, and in the relation between them (Papéis da Prisão 411). It is also evident in the "confusion" expressed by the more sensitive guards when faced with a deviation from the "natural order of things":

expectations. Note Luandino's citation of an Angolan colonial: "Funji? Pensam que somos negros?!" (Papéis da Prisão 780). 
Os guardas aqui são menos arrogantes e mais delicados. Insistem em nos querer dar um preso (preto) para as limpezas o que tenho rejeitado.... Faz-lhes "confusão" ver-nos de balde e vassoura e ir com o balde do lixo despejá-lo ao caixote.... (Papéis da Prisão 324)

In Papéis da Prisão, boundaries are laid bare not so much by the meticulous exposure of political positions, but through a vision of social, racial, and ethnic layers in the prison space. The prison comes to represent the Angolan nation and the city of Luanda, which Luandino's fiction paints as radically divided (from $A$ Cidade de Infância onwards) by what Sousa Santos terms a "linha abissal" (23) - a line dividing races, classes, resources, living conditions, and futures. The first drawing in Luandino's notebooks provides an example of his perception of Luanda as a divided city: a line cutting the landscape of two universes in the "City of Luanda," showing the city's design as a mirror of political, economic, and racial division. In the drawing, a physical line divides the city. It is cast as unmovable on the plane of representations that mold the city's flows. The spatial divisions of Luanda are allegorized in a way that retells the story from the position of the oppressed.

The musseque is in the foreground. From there, the artist looks toward the colonial city and forms his imminently political literary project. The city's representation through the perspective of the musseque serves to destabilize Eurocentrism and subvert the colonial way of imagining the city. By placing the musseque in the foreground, Luandino casts light on the unseen, those denied citizenship, in the Roman sense of the term. He gives voice and gaze to those that colonialism dehumanized - the very people whose labor sustained the colonial regime and whose presence also subverted it. In the picture, the city is an axis of social relations, portrayed by Luandino from his imprisonment. 


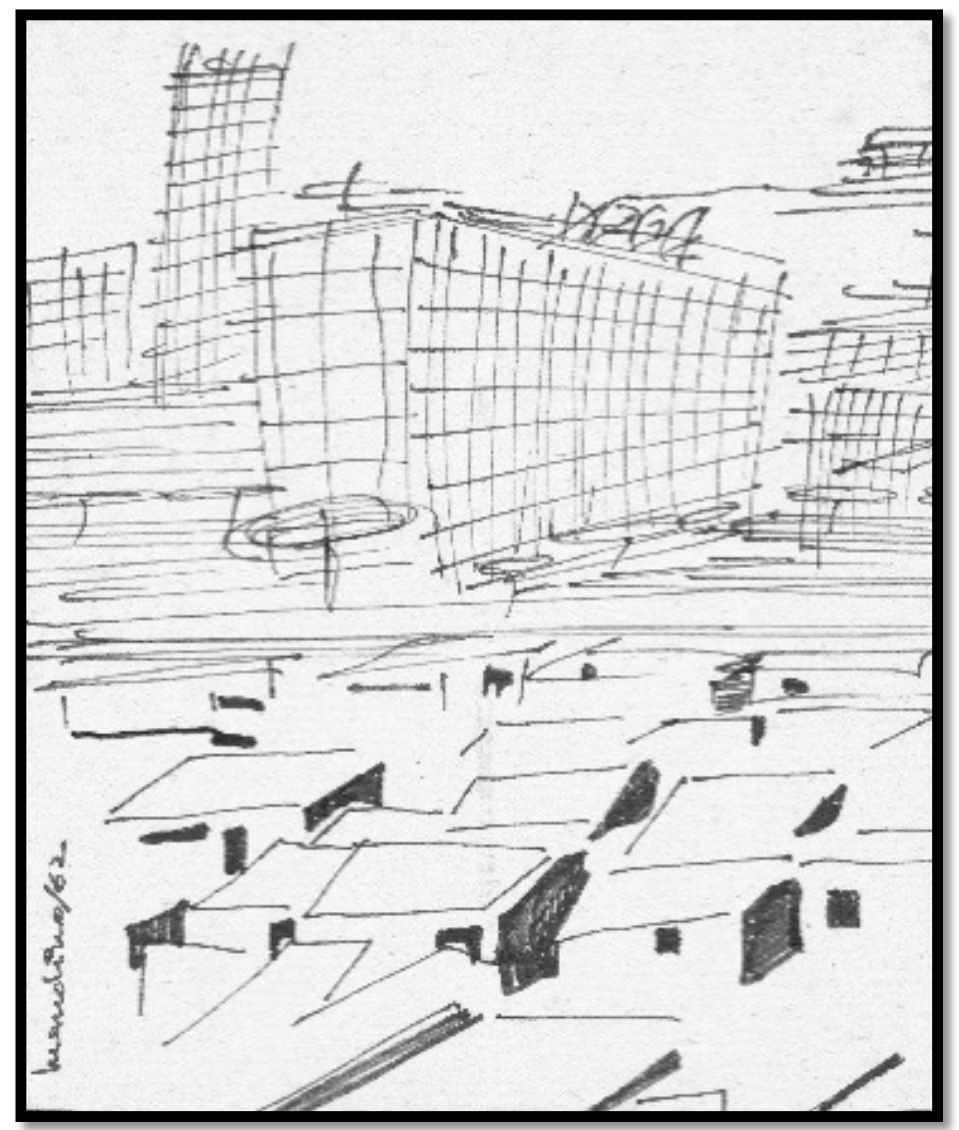

City of Luanda, 1962. (Papéis da Prisão 45)

Luandino transports his readers to the musseque through stories and the recounting of incidents that took place on the city's periphery. In the 18 January, 1964 notes on the common prisoner Mangololo's account of the events of February 1961, spaces and times intermingle. The description by Mangololo, "um produto já da "cidade" of Luanda, departs from a life in the present, at Luanda Civil Jail in 1964, to the same life in a past, in the musseques shortly after the 4 February, 1961 uprising (Papéis da Prisão 413). The sketches are a guided journey into the repression, fear, and obscene violence of Portuguese colonialism in various Luanda neighborhoods, such as Bairro Santo, Bairro Operário, Rangel, Marçal, Sambizanga, Lixeira and Xamavo: 
- Andou a dormir em casas de familiares e conhecidos do Bairro Santo (onde morava) para o B[airro] O[perário], daí para o Rangel, daí para o Marçal.... Todas as pessoas não dormiam, sempre à espera de sentir bater na porta e serem tiradas para a rua, onde eram mortas ... quando chegou no Marçal viu as casas ardidas e as coisas que os brancos traziam para a rua, mobílias, máquina de costura, rádio, tudo e começaram queimar no meio do largo (Papéis da Prisão 426).

Rusga no Sambizanga. Cercam c/ soldados e metralhadoras pelo chão, passando Lixeira, Bairro Santo, cercam por Xamavo até Lixeira pela estrada da Cuca. Aí começam a bater às portas de madrugada. Quem sai logo mostra documentos e segue para o grupo, sentam no chão 2 a dois, documentos na mão, mãos em cima da cabeça. Aquele que refilar a + pequena coisa (por exemplo: - Quem é a esta hora? Estamos dormir! etc. etc.) é logo marcado a giz com uma cruz na cabeça e mandado para o grupo especial; este grupo nem perguntam pelos documentos, segue logo de jipe e caminhão para a Pide.... (Papéis da Prisão 428)

Mangololo's is a disturbing account of the chaos in the musseques in February 1961. Beyond the reach of the floodlit watchtowers or the range of the searchlights of the patrol cars, we see underground trails, streaming into a protective cloak around relations of solidarity. The city, beyond its colonialist spaces and patterns, was woven by networks of sheer survival and underground struggle.

Another important aspect of Luanda as portrayed in Papéis da Prisão relates to human geography and space, enunciated in other languages and through other knowledges and poetics. While in prison, Luandino collected examples of musseque dialects manifested in the popular traditional songs of Luanda, and interpreted them as political acts that ensured continuity, by "perpetuar uma época da vida da comunidade" (Papéis da Prisão 465). ${ }^{8}$ A song composed in the Bairro Santo, which narrates the murder of four assimilados by Portuguese troops following a false accusation by the "famoso bufo, mulato, terror dos musseques"

\footnotetext{
${ }^{8}$ The songs collected were predominantly shared with Luandino by Amaral and Adrualdo dos Reis, two prisoners from Luanda, jailed as common criminals.
} 
(Papéis da Prisão 465), conveys both a particular incident in the life of the musseque and its place in a historical context. The song reveals boundaries as spaces of relationship. Luandino refers to the song as integrated "na realidade sócio-cultural dos musseques 'saiu' bi-lingue i.e. é hibrida apresentando partes em vernáculo, parte em termos do português já 'aquimbundado,' integrados na língua ... e outros ainda na pureza portuguesa" (Papéis da Prisão 465). With this kind of explanation, Luandino demonstrates how the "abyssal line" was porous because of the sheer complexity of the humans who lived on either side of it. In other words, Luanda may have been a set of disconnected, fragmented and isolated places as seen through a colonial optic (musseques and city), but it was also inevitably a network as a result of movements of labor, dependency and proximity, in which exchanges between both sides of the line were often unequal but occurred nonetheless. Gupta and Ferguson's injunction to put any discussion of the local in wider framework of relational dependency is useful to understand Luandino's context. According to Gupta and Ferguson, the differences that the city possesses should not be thought of as a fracturing line but rather as a relationship that results from the interconnection and interdependence of spaces (43). Therefore, the assimilation of dominant cultural forms should not always be seen as a one-sided, defining process. It is always inherently relational. From the perspective of urban studies, and drawing on Rossa's theory regarding the discourses of cities, the knowledge of the city makes it impossible to separate the lives of a city's inhabitants from the city itself (Rossa 477).

As well as their value as a testament to Luanda's social relations, the notebooks help us to understand how Luandino's literary project evolved. Due to the experiences he observed and his need to keep a firm grip on his lost childhood - a safe haven and place of evasion - Luandino selected Luanda and in particular the musseque as the scenario for his literary and political work. The musseque, with its laborers, languages and cultures, asserts the Angolan nation inside the city's space and delineates the city's battleground. Note the comments of fellow inmate Amadeu Amorim regarding Luuanda: “estilo 'nosso.' Há lá um bocado de nós próprios. Aqueles problemas existem. Não sendo verdade são histórias verdadeiras" (Vieira, Papéis da Prisão 586). ${ }^{9}$

\footnotetext{
${ }^{9}$ Amadeu Amorim, a Luanda native and founder of the musical group Ngola Rimos, was one of the political prisoners from the "Processo dos 50."
} 
In a letter to Luandino, referring to Luandino's book Vidas Novas (written in 1962 from the PPPIDE), Alfredo Margarido declares him "o caso mais singular de ficcionista inteiramente luandense, aquele onde é possível surpreender os movimentos de uma cidade ainda em gestação" (Vieira, Papéis da Prisão 379). Margarido praises Vidas Novas's ability to overcome the:

mundo da infância (ou seja o que ainda existia de saudade do paraíso perdido, do wonderland) para se integrar numa zona mais próxima da totalidade dos problemas do mundo periférico luandense ... pela $1 .^{\mathrm{a}} \mathrm{vez}$ na história parca da literatura angolana, se transfere deliberadamente para o musseque, abandonando a zona branca, que foi (repare neste pretérito) a única onde era possível afirmar alguma coisa. (Vieira, Papéis da Prisão 379)

In Vidas Novas Luandino presents the musseque as the political space of literary inscription and the prison as one of his most salient and constant characters. The short story "O Exemplo de Job Hamukuaja," dedicated to Godfrey Nangonja, a companion from the PPPIDE, is a fictional translation of this sentiment and portrays the interplay between the individual and the collective. The movements of the prisoners, their lives, languages, geographies, rituals and hopes, their screams and bruised bodies become evidence of strength through a collective spirit: "Podem-nos matar, não faz mal, companheiro. Somos milhões na nossa terra! Nossa luta é justa!” (112).

In Papéis da Prisão, prison was an issue of daily life. Fear of as well as actual imprisonment constrained the lives of people, inside and outside the prison walls. Reading Papéis alongside Luandino's other work, one sees how prison was fundamental to his fiction, not just in terms of refining his ideals and ideology, but also as a place where inspirations for his characters circulated, and atmospheres were captured. Examples include the story of Garrido (350) which became the short story, "A Estória do Ladrão e do Papagaio" in Luuanda or "O feitiço no bufo Toneto," which narrates the actions of João Santos, a "menino largado no musseque à toa, a mãe maluca de andar nas portas e o pai na Baía dos Tigres" (Vidas Novas 56). ${ }^{10}$ This account takes us through Luanda's musseque

\footnotetext{
${ }^{10}$ Prison in Tiger Bay, Province of Namibe, Angola.
} 
and subtly depicts a family breakup caused by imprisonment. In it, prison is a character that writes and inscribes part of the city's composition.

The similarities between the fictional prison and its real counterpart presented in Papéis da Prisão confirm that for Luandino prisons were intrinsic to the liberation movement. Writing was a responsible act in the fight against violence, repression, exploitation, and alienation, not because it crystalized time in a mythical past, but because it conveyed Luanda in its current terms, with its historical and geographic continuities and discontinuities.

\section{Final remarks}

Papéis da Prisão sketches a topography of Luanda's prisons, foregrounding the ideological battle lines between the colonial regime and the independence movements. It bears witness to the worsening of the conflict, and affirms prisons as breeding grounds for "angolanidade" and the struggle for freedom. Because of its vast array of materials and reflections, Papéis da Prisão paints a picture of Luanda as a space of conflict, a witness to Portuguese colonial oppression, and also of relationships, highlighting the weakness of any critical analysis that focuses only on the city's fractures, divisions, and isolation. As Luandino shows, Luanda was a space of flows, with movements across its borders, and different optics through which its conflicts could be read.

Luandino's Papéis da Prisão is a signifiant example of prison writing as an instrument in the fight for freedom in the twentieth century. It converges with the writings of others in assuming an anti-hegemonic position for the analysis of a particular time and a particular space. As Antonio Gramsci reminds us, any such time and place is made up of heterogenous wills, united because of their circumstances and their aspirations for the future (12-13). As he has it, they bring to the surface new ways of conceiving of human beings in the world (36). Referring to the importance of language as a product and reflection of a particular moment, Luandino exposes through his prison writings a new conception of the world that fights for freedom in Angola and, more generally, in Africa. As such, Papéis da Prisão preserves the memory of the struggle for the city, the nation, and for humanity in general. Or, as Luandino declares: "O meu amor à minha terra, Angola, é apenas a forma do meu amor pela humanidade." (Papéis da Prisão, 705). 


\section{Works Cited}

Andrade, Mário de. Antologia Temática de Poesia Africana 1. Na Noite Grávida de Punhais. Praia: Instituto Caboverdeano do Livro, 1980. Print.

Gramsci, Antonio. Concepção Dialética da História. Rio de Janeiro: Civilização Brasileira, 1987. Print.

Gupta, Akhil, and James Ferguson. Culture, Power, Place: Explorations in Critical Anthropology. Durham, NC: Duke UP, 2001. Print.

Medina, Maria do Carmo. Angola, Processos Políticos da Luta pela Independência. Coimbra: Almedina, 2011. Print.

Quijano, Aníbal, “Colonialidade do poder e classificação social.” Epistemologias do Sul. Ed. Boaventura de Sousa Santos and Maria Paula Meneses. Porto: Afrontamento, 2009. 73-117. Print.

Ribeiro, Margarida Calafate, and Roberto Vecchi. "Papéis críticos avulsos." Papéis da Prisão-apontamentos, diário, correspondência (1962-1971). By José Luandino Vieira. Lisbon: Caminho, 2015. 13-31. Print.

Rossa, Walter. "Urbanismo ou o Discurso da Cidade." Patrimónios de Influência Portuguesa: Modos de Olhar. Ed. Margarida Calafate Ribeiro and Walter Rossa. Coimbra: U de Coimbra, 2015. 477-519. Print.

Said, Edward. Humanismo e Crítica Democrática. Trans. Rosaura Eichenberg. São Paulo: Companhia das Letras, 2007. Print.

Santos, Boaventura de Sousa. Epistemologias do Sul. Coimbra: Almedina, 2009. Print.

Vieira, José Luandino. Papéis da Prisão-Apontamentos, Diário, Correspondência (1692-1971). Lisbon: Caminho, 2015. Print.

-. Vidas Novas. Lisbon: Caminho, 2007. Print. 